\title{
Toward Indonesia as Global Maritime Fulcrum: Correcting Doctrine and Combating Non-Traditional Maritime Threats
}

\author{
Maula Hudaya \& Agung Tri Putra \\ Universitas Airlangga
}

\begin{abstract}
Indonesia is the largest archipelagic country in the world and has enormous potential in the maritime sector. Therefore, President Joko Widodo aimed to turn Indonesia into a maritime fulcrum of the world. However, this idea hampered by doctrinal errors rooted from the community level to policymakers, including the doctrine of state defense. These errors rendered Indonesia unable to play an important role using its strategic location as the largest archipelagic country. Furthermore, piracy culture in some coastal communities of Indonesia is also a problem that hinders international trade. Moreover, this condition is further exacerbated by the threat of maritime terrorism that endangered Indonesian seafarers. This paper uses the theoretical foundation by Alfred Thayer Mahan on Sea Power to analyze what kind of policies should be taken by the government to solve the maritime security holes in order to actualize the idea of Indonesia as the maritime fulcrum of the world. Mahen stated that to become a powerful country in the world, a country should have control over the oceans. Through this theory, solving maritime security holes in Indonesia can be conducted by accumulating the strength of the sea in quantity and quality.
\end{abstract}

Keywords: global maritime fulcrum, non-traditional threat, maritime terrorism, security holes, and absolute control.

Indonesia merupakan negara kepulauan terbesar di dunia dan memiliki potensi yang besar di bidang maritim. Oleh karena itu, Presiden Joko Widodo berniat menjadikan Indonesia sebagai poros maritim dunia. Namun, gagasan ini terhambat oleh kesalahan beberapa doktrin yang berkembang di tingkat masyarakat hingga pembuat kebijakan termasuk doktrin pertahanan negara. Kesalahan ini membuat Indonesia tidak dapat memainkan peran penting dengan lokasinya yang strategis serta sebagai negara kepulauan terbesar di dunia. Selanjutnya, keberadaan budaya pembajakan di masyarakat pesisi Indonesia turut menjadi masalah yang menghambat perdagangan internasional. Kondisi ini semakin diperparah dengan ancaman terorisme maritim yang membahayakan pelaut Indonesia. Tulisan ini menggunakan dasar teoritis Alfred Thayer Mahan mengenai Sea Power untuk menganalisis jenis kebijakan apa yang harus diambil oleh pemerintah guna mengaktualisasikan gagasan poros maritim dunia. Mahan menyebutkan bahwa untuk menjadi negara kuat harus memiliki kenadali atas laut. Melalui teori ini, menyelesaikan celah keamanan maritim di Indonesia harus dilakukan dengan mengakumulasi kekuatan maritim secara kualitas maupun kuantitas.

Kata-kata Kunci: Poros maritim dunia, ancaman non-tradisional, terorisme maritim, celah keamanan, kontrol absolut 
Indonesia is the largest archipelagic country in the world consisting of 17,499 islands from Sabang to Merauke (BPHN 2015). Not only it has a very large number of islands, Indonesia also has 3.25 million square kilometers water territory plus an Exclusive Economic Zone of 2.55 million kilometers, making its water territory larger than the land (2.01 million square kilometers) (BPHN 2015). According to Santikajaya (2014), Indonesia has a very strategic location in Malacca Strait which is the intersection of world maritime road, from Indian Ocean to Pacific Ocean. Malacca Strait is one of the most crowded maritime routes in the world and an important choke point for merchant ships which passed through it. This condition becomes very potential for Indonesia; therefore, it is necessary to have the right policy and strategy to take advantage of Malacca Strait. This promising natural condition is a strong reason for President Joko Widodo to create a new foreign policy idea by realizing Indonesia as the global maritime fulcrum. Furthermore, behind the strategic geographical conditions, historical factors of Indonesia about the history of the ancient kingdoms of Sriwijaya and Majapahit as maritime rulers also influence maritime policy of President Jokowi. Joko Widodo clearly expressed his goal to make Indonesia a global maritime fulcrum in his speech at the East Asia Summit in Myanmar's Nay Pyi Taw on November 13, 2014. President Jokowi pointed out that Indonesia's development as a global maritime fulcrum will be focused on the five pillars. The first pillar is to rebuild Indonesia's maritime culture. The second pillar is to protect marine resources and create food stability by placing fishermen as the organ on this pillar. The third pillar is to give priority to infrastructure development and maritime connectivity by building sea tolls, deep seaport, logistics, shipping industry, and maritime tourism. The fourth pillar is to apply maritime diplomacy through proposed enhancements of maritime cooperation and conflict management, such as fish theft, sovereignty offenses, territorial disputes, piracy and marine pollution, assuming that the sea should unite the nation and not to separate. Then the last pillar is to build maritime power as a responsibility to protect the security of maritime shipping and maritime security (Kementerian Luar Negeri RI 2014).

Although global maritime fulcrum in question is not only about the naval power, as expressed by President Jokowi on the fifth pillar, the aspect of power becomes very important. It would be useless to be a global maritime fulcrum in economic field alone, but does not have 
the capability to secure marine territory that becomes the exploited commodity in own country. The authors argue that Indonesia should focus more on strengthening its own fleet, not to challenge the US command of the sea, nor to present a strong presence naval to dispel China in the South China Sea. Indonesia has to start from small things, by securing its own territorial waters and the surrounding waters from maritime threats, especially non-traditional ones. Although in the fourth pillar, the president mentioned that there are many issues to be addressed, but in this paper, the authors will focus only on non-traditional maritime issues, piracy and terrorism. The authors choose these problems because piracy greatly hampers the development of global maritime fulcrum. Furthermore, maritime terrorism with the presence of the Abu Sayyaf group, as well as the rise of mainstream terrorist groups that are spread, can also disrupt the maritime policy of Indonesia. In addition, there is a fundamental problem that must be solved first in order to smooth out Indonesia's step towards global maritime fulcrum, the doctrinal errors that have been embedded from the community level to the doctrine of defense.

\section{Fundamental Doctrine Issues}

Despite its great potential to be the world's greatest maritime power, but these abundant potentials are not well-utilized. This is due to the fundamental doctrinal errors that have been implanted on Indonesian society since the first time, that Indonesia is an agrarian country. It is not entirely wrong, but continuous indoctrination indirectly creates a paradigm that Indonesian people have an agrarian spirit and further degrade Indonesia's national identity as a maritime nation which can actually live from marine products, not only to cover the needs of the community, but also to become a profitable export commodity. The doctrinal error is also reflected in the explanation of "Indonesia as an archipelagic country". The authors see that the explanation also builds perception so that they focus on the concept of land, not the sea, so that the identity formed is the identity of the Indonesian nation as an agrarian country, as mentioned earlier. Doctrinal error is not only spread at community level, but also in state and defense doctrine which is centered around ground forces. This doctrine of defense is also reflected in the concept of guerrilla warfare and hankamrata which became one of Indonesia's strategic cultures. General A.H. Nasution (1984) in 
his book entitled "Guerrilla and Our Upcoming War" states that guerrilla warfare is the responsibility of the people along with TNI. Nasution also explained the resistance of European countries to Nazi Germany and Japan in World War II, guerrilla warfare was defined as an important mean of warfare for Indonesian people in terms of geographical conditions as an archipelagic country. The possibility of foreign attacks on the territory of Indonesia might be worrying, so this guerrilla war focuses on the core forces and the leaders. Although Nasution (1984) also stated that there should be a balanced synergy between the three armed forces, it appears that the role of the Air Force and the Navy is only as a supportive power of the army.

Guerrilla warfare involving civilians only works on land and is not suitable for Indonesia's geographical conditions with vast maritime territory. Lieutenant General, T.B. Simatupang. stated that the guerrilla would not succeed without a qualified sea power, because if the straits of Indonesia are controlled by the enemy, then the guerrilla tactics would not end. Therefore, Simatupang (1981) emphasized on increasing the strength of the sea and returning Indonesian people who "have been on the ground too long" to the sea. Basically, the doctrines and strategic culture of Indonesia have indeed been constructed by the history of the nation in terms of its resistance against Dutch colonial power in which guerrilla successfully expelled the invaders. However, the conditions are not always the same. If the doctrine of defense and strategic culture which put too much emphasis on ground forces has not been altered, the fourth pillar of maritime fulcrum will also be hampered. Although guerrilla doctrine focuses on traditional threats such as the invasion of other countries, ground-based doctrines can also weaken the state in the face of various non-traditional threats as mentioned by the authors before. The only possible path for Indonesians to tackle maritime terrorist and piracy problems is to add its fleets. This is in line Alfred Thayer Mahan (1890) thesis that to control the sea is not related to how big the sea is, but how many boats are owned and how strong the operated ports.

Referring to UNCLOS 1982 Article 101, piracy is defined as violence occurred on the high seas beyond the territorial waters of a country (Young and Valencia 2003). While International Maritime Bureau (IMB) defined that piracy is an act of step into a ship or attempting 
to board a ship with a clear intention to commit theft or other crimes and with the purpose or ability to use force as continuation of such actions. Young and Valencia (2003) then divided piracy into several categories based on the assumption that the higher the risks and possible benefits, the more vulnerable it will be to violence. There are several categories of piracy method. First, the theft at the port with less risk and relatively little profit, because it only allows thieves to take small items, such as money and electronic equipment. For the first category, violence also infrequently happens, because it is done by slipping. The second is hit and run method, which is almost similar with the first one. This kind of crime is usually less organized. Thirdly, temporary seizure method which is piracy with big capital and risk, because this method requires seizing a vessel which need some supporting facilities, such as small boats or speedboats. Then it also requires equipment and people to control the crew, then takes the cargo carried by the ship. Then at a higher level, there is a longterm seizure and permanent theft method. Basically, they are almost the same as temporary seizures, but this piracy takes longer to find a safe harbor or other vessels to move cargo from a hijacked ship, and sometimes it involves some hostages.

Piracy has long become a serious threat to Indonesia. Piracy culture has existed in Indonesia since Sriwijaya period. However, piracy at that time is not the same as Blackbeard's crime, however the definition of piracy in Southeast Asia in that period was closer to the definition of privateering in the western world (Young and Valencia 2003). In those days, privateering was employed by empires like Sriwijaya, Aceh, Malacca, Johor, and Sulu to disrupt other kingdoms' economy through undetected commerce raiding (Young \& Valencia, 2003). Based on such argument, it seemed that kingdoms of the era deliberately kept the pirates to be used to attack the opponent without knowing that the attack was the act of a kingdom. On the other hand, the pirates also obeyed as long as the kingdom offers appropriate advantage. The statement is in line with Barnard's (2007) notion that there have been some groups living around Malacca Strait and have controlled the seas for several millennia, the group was then referred to as "Sea People (Orang Laut)" or "People of the Sea" by society. Orang Laut are the guardians of the Malacca Strait described as a major toll road, where Orang Laut are patrolling and guiding merchant vessels through dangerous waters. Barnard (2007) also explained that Orang Laut lives under the auspices of any 
kingdom which benefits them, and in some cases, they also act as privateers.

Opportunist attitude of pirates has become their trademark, even in this contemporary era. Contemporary pirates still haunt Indonesian waters to this day, especially in Malacca Strait. Young and Valencia (2003) proved that even though pirates in Southeast Asia was successfully eradicated by western colonial forces occupying Southeast Asia, but it bounced back and showed a significant increase, starting from 1997. There were only 22 cases until 2002, then it rose to 164 cases. This amount of threats made Southeast Asia the most dangerous waters in the world at that time. The authors argue that strategic location of Malacca Strait was the main cause of the high level of piracy. In line with this thought, Chatterjee (2014) argued that Malacca Strait is a very important chokepoint connecting some busiest trade routes from the Indian Ocean to the Pacific Ocean, so it is appropriate to call it as a crossroads of the world. With its very strategic position and supported by poor security to monitor the entire region, it has become a haven for the pirates. Although Chattarjee (2014) stated that there was a drastic decline of 79 piracy cases in 2005, 50 cases in 2006, two experiments in 2008, one trial in 2009, and almost no cases in 2012-2013, but Indonesia remains the country with the highest piracy rate among ASEAN countries and the world from 2012 to 2014 based on IMB data (Sindo News 2015). While the data published by Dinarto (2016) from ICC-IMB showed a drastic increase in 2011 from 46 cases to 108 cases in 2015, while data showing the incidents that occurred in Malacca Strait is relatively small, that is only 9 incidents by 2015 .

Moreover, Sindonews (2015) also revealed several incidents occurred in February 2015, including the hijacking of tanker KM Rebohot in Maluku waters. On May $27^{\text {th }}$, 2014, a Thai-flagged tanker, MT Orapin 4, was hijacked en route from Singapore to Pontianak, Indonesia. On June $25^{\text {th }}, 2014$, navy warship, KRI Keris, managed to thwart an attempt to hijack a Taiwanese-flagged fishing boat in the northern waters of Lombok, West Nusa Tenggara. On July $15^{\text {th }}$, 2014, there was a piracy conduct against MT Oriental Glory, a tanker sailing from Sandakan Malaysia to Bintan Island. On July $4^{\text {th }}$, 2014, Hondurasflagged MT Moresby was hijacked on its way from the Anambas Islands of Indonesia. On November 21 ${ }^{\text {st }}$, KRI Fleet Command West Area (Koarmabar) incorporated under Cakra Arnawa operation and 
Indonesia-Singapore Border Security Operation managed to thwart an attempt to hijack a Panama-flagged tanker, MV New Emerald, on Philips Starts. SindoNews (2015) further mentioned that on average, one small tanker is hijacked every 2 weeks. According to ICC data (in Dinarto, 2016), several cases of armed piracy conducted at some ports recorded fairly high numbers. It was not less than 53 cases or equivalent to $65 \%$ in 2012, then increased to 84 cases in 2013 or $79 \%$, then declined slightly to 77 cases or $77 \%$ in 2014 , and increased again in 2015 at 89 cases or about $82 \%$ of all incidents occurred that year. Based on the data, the most vulnerable ports are Bintan Island, Karimun Besar, Karimun Kecil, and Belawan.

High rate of piracy cases demonstrated huge holes in Indonesia's maritime security system. Bustling commercial ships stopping in Indonesia would be an opportunity for the pirates to act. The weakness of the maritime security system will have a direct impact on Indonesia's credibility in international relations. If it happens due to Indonesia inability to handle piracy incidents, other countries will be hesitant to send merchant ships to Indonesia, though foreign ships might still pass through Malacca Strait to reach its destination. Furthermore, Indonesia's security holes in its ports also become one of the factors why Indonesia is lagging behind Singapore as the main port and international stopover in Malacca Strait. Since Singapore is considered safer, international ships passing through the Straits of Malacca would prefer to stop at Singaporean ports compared to Indonesian ports. This problem is considered as the main obstacle to achieve Indonesia's goal as a global maritime fulcrum. Even if Indonesia is strong economically and in trades, but if Indonesia is unable to strengthen its naval presence to secure all economy activities in the sea, it shall render those strengths useless. In addition, Indonesia must ensure the security of trade ships from all over the world, if it wants to take over Singapore position as an international port in Malacca Strait. Not only that, the Malacca Strait is also one of the most important keys, if Indonesia wants to advance its trade in order to realize the global maritime fulcrum policy. Indonesia's stability as an archipelagic country is also strongly influenced by its maritime security (Son 2015). 


\section{Maritime Terrorism}

Terrorism, according to Hoffman (2006 in Graf 2011), is defined as the creation and dissemination of fears intentionally through violence or threat of violence in order to create political change. While maritime terrorism is often considered similar to piracy, but both have been different, starting from its motive (Young and Valencia 2003). The motive of terrorism is political and/or religious interests, whereas piracy is purely due to the greed of wealth. So that Young and Valencia (2003) called terrorism as political piracy because behind the maritime terrorism act, there is always a factor of political interest that pushed it. Although some authors such as Stefan Eklof Amirell consider political piracy to be different from maritime terrorism as well as piracy (Graf 2011).

Young and Valencia (2003) explained that there was a common strategy between maritime terrorism and piracy, as demonstrated by two groups of political piracy or maritime terrorists who haunt Southeast Asia, namely Free Aceh Movement (GAM) and Abu Sayyaf group in the Southern Philippines. GAM had political power to liberate Aceh from Indonesia and always strived to achieve these goals through various means, one of which is piracy. There were evidences that several pirate incidents in Aceh waters were linked to the organization, following the escalation of GAM and central government's conflict in 1998. The most notable incident was the attack on MV Ocean Silver by a group of Pirates armed with firearms and grenade launchers on August 2001. Six out of $12 \mathrm{crew}$ members were held hostage with a ransom equivalent of 30,000 US Dollars (Herbert-Burns and Zucker 2004 in Graf 2011). After this incident, GAM spokesman, Ishak Daud, secretly acknowledged his organizational involvement in the attack by demanding the shipowner to recognize GAM territory over Aceh waters: "If they (the shippers) do not want to ask permission from us, they should do not blame GAM when cases like those of the Honduran Ocean Ship are repeated" (Amirell 2006 in Graf 2011). GAM, as suggested by this incident, uses piracy as a source of funding for at least some parts of the organization's activities.

Abu Sayyaf which is classified as economic-oriented maritime terrorism by Graf (2011) for using terrorist instruments as a tactic for economic gain has a similar strategy to GAM's frequent capture 
of ship crews in Mindanao and Sulawesi waters. In 2004, the group even blew ferries which transported hundreds of passengers, Super Ferry 14, shortly after leaving the port of Manila, resulting in death of 116 passengers (Nctc 2014). The economic motive of Abu Sayyaf group is seen from the various acts of piracy and kidnappings carried out against foreigners crossing the Philippine waters. In 2001, the group abducted 20 tourists, including three US citizens (Counter Extremism 2017). The kidnappings and hostages were also experienced by two Indonesian barge vessels, Tunda Brahma 12 and Anand 12, in Borneo waters in early 2016 with 10 Indonesians as hostages (BBC 2016), Furthermore, Abu Sayyaf kidnapped two more Indonesians in Sabah waters and in close proximity five Indonesian citizens also fell victim in December 2016 to January 2017 (BBC 2017). Although economic-oriented, but Abu Sayyaf cannot be classified as pirates, but as maritime terrorism. This is because there is a very strong political motive that underlies the group's actions from its inception to the present day.

Abu Sayyaf group was founded in 1990 after secession from Moro National Liberation Front (MNLF) due to ideological factors. There was a refusal to grant special autonomy to Moro Muslims but wanted something much larger than Moro independence from the Philippines, as the Philippines was considered to have been too long oppressive and alienate Moros and the entire Muslim community in Mindanao (Nctc 2014). Looking at Abu Sayyaf's track record, the authors see that there is a pattern that illustrates how the group acts. Abu Sayyaf usually carries out major acts of terror, such as bombings, as they did to Super Ferry 14 which killed hundreds of peoples. Its goal is to spread threats and intimidate government and wider community, as well as to create a slow but steady political shift. Then, when the group's finances are not stable, they conducted pirates attack and hostage actions, targeting barges and fishing boats and merchant ships passing in waters near their operational areas. This issue poses a very serious threat and should be a priority for the Indonesian navy, because abductions will always occur since Abu Sayyaf always needs fund to maintain its existence, especially to recruit new members and rejuvenate weapons. Even a commander of the MNLF, dubbed "The Lion Heart", puts that although Abu Sayyaf members are less than MNLF, the strengths of the two groups are equal, because Abu Sayyaf's weapons are diverse and sophisticated for insurrection groups (Net 2016). 
GAM is no longer a threat to Indonesia's waters because it was dissolved in 2005, but the threat from the Abu Sayyaf group remains a danger for by Indonesian seafarers, especially with the opening of a new trade link between Indonesia and the Philippines, the port of Bitung to Davao, Mindanao via the Sulawesi Sea (Tribun News 2017). Maritime terrorism is rarely done because generally maritime targets cannot produce casualties as much as land or air targets. Additionally, to be able to attack maritime targets requires special skills that must be trained first (Bateman 2006). However, it also cannot be ruled out that sea targets have a wider security gap to be attacked. It is due to much higher level of difficulty and more expensive price in securing the sea than securing airspace and land (Bateman 2006).

Such holes can be used easily if the terrorist group has capabilities like Abu Sayyaf. The presence of Abu Sayyaf in Southern Philippines waters directly bordering Indonesia also poses a highly serious threat to Indonesia, because the group can disrupt trade activities leading and leaving Indonesia through these waters. Additionally, taking Indonesian citizens as hostages is also intolerable problem. Although the group does not want political change in Indonesia, but in the Philippines, this group sparked fears in various regions, especially Indonesia, Malaysia and the Philippines. In addition to Abu Sayyaf, Indonesian government should also ignore other terrorist groups such as Jemaah Islamiyah (JI) which Bateman (2006) reportedly had a joint military exercise with Abu Sayyaf in Mindanao, including training in maritime terrorism techniques. There is possibility that more terrorist groups will have maritime capabilities and will use it to take advantage of maritime security gap. If it happens, then most likely Indonesian terrorist networks with maritime capability will target both trading vessels and passenger ships. Possible scenarios include long-term seizure to permanent theft or piracy with hostagetaking with the economic goal of ransom money, then the hijacked ship can be reused to attack others. The attack scenario can also be done by installing a bomb on a boat and blowing it up near another vessel or facility. If the terrorists have great power, then ports and other facilities, such as Indonesia's offshore oil refineries, can also be the target of attack. 


\section{Policy Recommendation for Indonesian Government}

In general, Young and Valencia (2003) explained that there are several ways to overcome the case of piracy and terrorism, namely through the initiative of the United Nations and external parties embodied through Convention of Rome and SUA. However, both are rejected by the countries of Southeast Asia, because they are considered only benefiting a country with strong maritime capabilities and US and India cooperation to patrol Malacca Strait. Furthermore, it aroused suspicion in the region and was considered jeopardizing sovereignty. A more effective way is through regional cooperation. Regional cooperation can be realized by raising the issue of maritime piracy and terrorism in ASEAN Maritime Forum (AMF) and followed up by forming a joint patrol between ASEAN countries, so that no one feels suspicious and harmed. Moreover, the local countries will understand more about territorial waters, so it can narrow down the space for pirates and terrorism. In addition, bilateral and multilateral forums between its marine states are infected by terrorist and pirate threats. There was also a meeting between three defense ministers of Indonesia, Malaysia, and the Philippines to discuss joint patrol plans to tackle the Abu Sayyaf threat which directly impacts the three countries.

For Indonesia, safeguarding its marine areas from piracy and terrorism is crucial. Because it greatly affects its credibility and dangerous waters also affects trade which is crucial for economic development in Indonesia. The weakness of Indonesia's maritime security also shows Indonesia's unpreparedness to achieve its objective as global maritime fulcrum. If we look at previously described, particularly about the most frequent piracy cases in ports, Indonesia should consider increasing the number of security personnel, especially navy and full-armed seafarers on every ship in port and put them on standby for 24 hours to minimize piracy or ship theft when it is moored. Moreover, security can also be maximized by adding high-speed light vessels in each port aim to pursue the pirates.

Additionally, to tackle piracy and offshore terrorism, Indonesia should not only focus on Malacca Strait, because many cases did not only occur there, but also in Kalimantan and Sulawesi waters. Furthermore, presence of Abu Sayyaf and ISIS occupation in Marawi, 
the Philippines, also haunt Indonesia due to possible migration of Marawi jihadists to Indonesia by sea; thus, the security of Indonesia coastline should be tightened. The authors also note that the discourse of transferring the headquarters of the Eastern Fleet Command (Koarmatim) from Surabaya to Kalimantan or Sulawesi, as well as forming a new fleet commands, personnel addition, strengthening weaponry, needs to be seriously considered. Extending the Navy's reach and addressing the security challenges in these waters are also necessary to secure international ports, especially if arctic trance trade routes are officially opened. However, since it requires a lot of money, government also needs to consider increasing Navy budget to enhance their weaponry to maintain the waters of Indonesia. Essentially, the concentration of Indonesian marine security should be more focused on patching the existing gaps by intensifying Navy patrol. The authors also consider applying marine guerrilla method to observe the movement of suspicious ships with satellites or drones, and then disguise some Navy personnel as tanker's crews and other commercial vessels to lure pirates and arrest them right away.

\section{Conclusion}

Indonesia has one of the greatest maritime potentials in the world. Unfortunately, there are various doctrines that actually degrade the idea of Indonesian seafarers. Therefore, it is necessary to return Indonesian people to the sea, so that the ideals of Indonesia as a maritime axis of the world can be achieved. However, Indonesia should be able to ensure its maritime security by addressing the problem of piracy and non-traditional terrorism. Therefore, the authors argue that Indonesia should start from presenting a suitable naval presence to safeguard internal waters first. Then, if it succeeds in overcoming piracy and terrorism in its own territory, Indonesia must take over the seat driver's position in the war against pirates and terrorism in Southeast Asia and become world maritime axis. 


\section{References}

Barnard, Timothy P, 2007. “Celâtes, Rayat-Laut, Pirates: The Orang Laut and Their Decline in History", dalam Journal of the Malaysian Branch of the Royal Asiatic Society, Vol. 80, No. 2, pp. 33-49.

Bateman, Sam, 2006. Assessing the Threat of Maritime Terrorism: Issues for the Asia-Pacific Region. Security Challenges Vol. 2 No. 3, pp. 77-91.

BBC, 2016. Dua kapal Indonesia dibajak di Filipina, 10 WNI disandera. [online] http://www.bbc.com/indonesia/berita_ indonesia/2016/03/160329_indonesia_kapal_dib ajak_filipina [Accessed on Juli 11, 2017].

BBC, 2017. Tujuh WNI diculik dan disandera kelompok Abu Sayyaf. [online] http://www.bbc.com/indonesia/indonesia-38837392. [Accessed on Juli 11, 2017].

BPHN, 2015. Indonesia Merupakan Negara Kepulauan yang Terbesar di Dunia. http://bphn.go.id/news/2015102805455371/ INDONESIA-MERUPAKAN-NEGARA- KEPULAUANYANG-TERBESAR-DI-DUNIA. [Accessed on Juli 9, 2017].

Chatterje, Aditi, 2014. Non-traditional Maritime Security Threats in the Indian Ocean Region. Maritime Affairs Vol. 10 No. 2, pp. 77-95.

Counter Extremism, 2017. Abu Sayyaf Group. https://www. counterextremism.com/threat/abu-sayyaf-group. [Accessed on Juli 11, 2017].

Dinarto, Dedi, 2016. Indonesia Needs to Step up Its Fight Against Maritime Piracy. http://thediplomat.com/2016/12/indonesianeeds-to-step-up-its-fight-against-maritime- piracy/.[Accessed on Juli 11, 2017].

Graf, Andreas, 2011. Countering Piracy and Maritime Terrorism in South East Asia and off

The Horn of Africa http:/ / maritimesecurity.eu/ fileadmin/content/ news_events/workingpaper/PiraT_Arbei spapier_Nr4_2011_ Graf.pdf. [Accessed on Juli 10, 2017].

Kementerian Luar Negeri Republik Indonesia, 2014. Presiden Jokowi Deklarasikan Indonesia Sebagai Poros Maritim Dunia. https:// www.kemlu.go.id/id/berita/siaran-pers/Pages/PresidenJokowi-Deklarasikan- Indonesia-Sebagai-Poros-Maritim-Dunia. aspx. [Accessed on Juli 11, 2017]. 
Mahan, A. Thayer, 1890. The Influence of Sea Power Upon History, 1660-1783. Barnes dan Noble Books.

Nasution, Jenderal A.H., 1984. “Gerilya dan Perang Kita yang Akan Datang", dalam Pokok Pokok Gerilya dan Pertahanan Republik Indonesia di Masa Lalu dan yang Akan Datang. Bandung: Penerbit Angkasa, pp. 77-117.

Nctc, 2014. Abu Sayyaf Group (ASG). [online]

https://www.nctc.gov/site/groups/abu_sayyaf.html. [Accessed on April 8, 2017].

Net News, 2016. NET Special Report: Penelusuran Kelompok Bersenjata Abu Sayyaf di Filipina. [online] https://www.youtube.com/ watch?v=EqSjw4OojWw\&t=94s. [Accessed on Juli 4, 2017].

Simatupang, Mayjen T.B., 1981. Pelopor dalam Perang Pelopor dalam Damai. Jakarta: Penerbit Sinar Harapan, pp. 198-240.

Sindo News, 2015. Kawasan Laut Indonesia Paling Rawan Perompak. https:/ / nasional.sind onews.com/read/1016307/149/ kawasan-laut-indonesia-paling- rawan-perompak-1435115132. [Accessed on Juli 11, 2017].

Son, Nguyen Hung. 2015. ASEAN-Japan Strategic Partnership in Southeast Asia: Maritime Security and Cooperation. http://www. jcie.org/japan/j/pdf/pub/publst/1451/12_nguyen.pdf. [Accessed on Juli 10, 2017].

Tribunnews. 2017. Adanya Layanan ini, Pengiriman Barang Indonesia Filipina kini Cukup 1,5 Hari. [online] http:/ / surabaya.tribunnews. com/2017/03/07/adanya-layanan-ini- pengiriman-barangindonesia-philipina-kini-cukup-15-hari. [Accessed on April 8, 2017].

Young, Adam J. and Valencia, Mark J., 2003. Conflation of Piracy and Terrorism in Southeast Asia: Rectitude and Utility. Contemporary Southeast Asia, Vol. 25, No. 2, pp. 269-283. 